\title{
BioMed Central boosted by editorial board
}

Declan Butler

The idea that the primary scientific literature should be available online free of charge gained heavyweight support this week, when ten prominent biomedical scientists agreed to join the editorial board that advises on BioMed Central's (BMC) overall goals.

The new publishing house, which is owned by the Current Science Group (see Nature 402, 110; 1999), started accepting papers this week. It will peer review and publish free on the web papers across the biomedical sciences.

The ten scientists include Elizabeth Blackburn of the University of California, San Francisco, Steven Hyman, director of the US National Institute of Mental Health, Marc Kirschner, head of the Department of Cell Biology at Harvard Medical School, Philippe Kourilsky, director-general of the Institut Pasteur in Paris, Paul Nurse, director-general of the Imperial Cancer Research Fund in London, Harold Varmus, president of the Memorial Sloan-Kettering Cancer Center, and Mitsuhiro Yanagida, president of the Molecular Biology Society of Japan and Kyoto University.

BioMed Central will accept papers in around 50 disciplines, such as neuroscience, virology and developmental biology. As well as referees, each area will have a series of coordinating scientists.

Reviewers will assess scientific accuracy, not interest, says Harvey Shoolman, BMC's editorial coordinator. For example, he says, it will publish negative results and details of single experiments.

Accepted papers will be accessible at http://www.biomedcentral.com and archived on PubMed Central (PMC), the free repository for life-science papers launched earlier this year by the US National Institutes of Health. Copyright will remain with authors. If BMC takes off, it will give a boost to PMC, which at the moment contains material from only a handful of journals.

"Our central task will be to persuade authors to publish with us," says Vitek Tracz, chief executive officer of the Current Science Group. "We don't know how big or small the problem will be."

He adds that the group will use technology to offer carrots such as accelerated publication and efficient searching. It will also recruit scientists to highlight important papers as they are published.

Editorial board member Joseph Martin, dean of the faculty of medicine at Harvard Medical School, is one of many who argues that scientists are unlikely to shift en masse from print to electronic journals. He says this is precisely why a strong signal from leaders of the biomedical establishment was needed.

Hyman admits that "BioMed Central is not the only way to skin a cat". But he says he agreed to join the board to send a signal that many biomedical researchers believe that the

\section{Russian PM supports science}

\section{Carl Levitin, Moscow}

Russian science appears to have a friend in the country's new prime minister, Mikhail Kasyanov - at least in principle. In a major address to the lower house of the Russian parliament last week, Kasyanov said: "We now have entered the information epoch" where knowledge is "of principal importance".

He went on to say that "the development of education and promoting basic and applied research in the sphere of modern technologies should be considered as the most important investment in our country's future". But despite this show of concern, the new government will operate without the former Ministry of Science and Technologies.

Kasyanov has reduced the overall number of ministries from 30 to 24 . Science now comes under a single Ministry of Industry, Science and Technologies. Headed by Aleksandr Dondukov, 46, the new ministry will be responsible for many aspects of Russia's economy, including its industrial development, military production

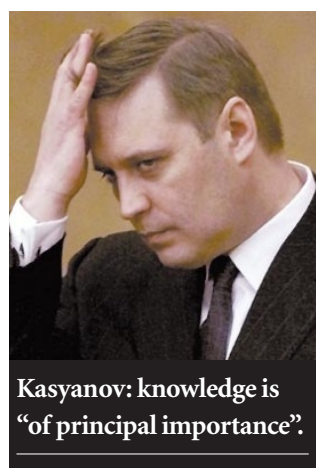

and arms exports. Many fear that basic science will not be high on its list of priorities. Dondukov graduated from the Moscow aviation university in 1957, and worked on aircraft design in several Soviet and later Russian design bureaux. In 1994 he was appointed chairman of the directors' council of the Yakovlev Design Bureau in Moscow.

His stated ambition was to centralize control of aircraft production in Russia by working closely with the aviation research and development offices of the former Soviet Union republics. He is not known to have previously expressed any interest in basic research or educational programmes.

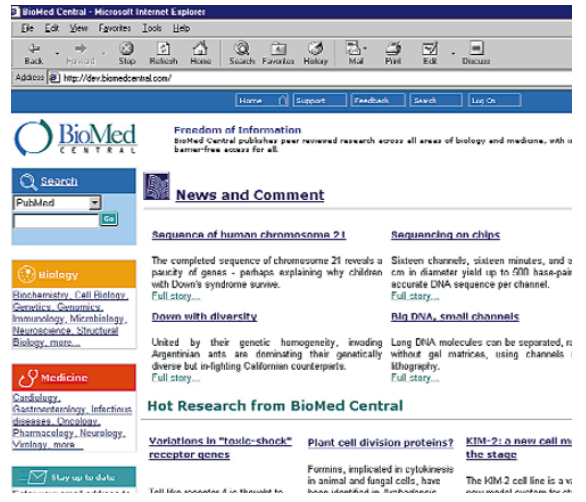

BioMed Central: will provide free access to peer-reviewed research.

current system of journals is obsolete, and that the Internet offers improved alternatives.

Like many scientists, both Martin and Hyman say they read only a handful of the top journals. For the rest, their main need is to be able to search the primary literature without running up against the subscription firewalls of thousands of journals.

"If I cannot access a paper freely I just ignore it," says Hyman, adding that, although he "respects the peer review provided by the existing journals system", he feels that this could be maintained within an electronic database of the primary literature.

Both men argue that the bulk of the biomedical literature is 'balkanized' across thousands of low-impact journals, and that scientists would be better served by a seamless, searchable and freely accessible database. "We pay for the science, why should the journals get copyright?" says Hyman, arguing that the Internet makes the cost of publication derisory compared with the cost of producing the research in the first place.

One big question is how BMC is going to pay for the services it will provide. Shoolman says it can afford to run at a loss for some time thanks to Tracz's personal fortune. For his part, Tracz says that "the business model is unknown to everyone, including me, but we are confident we have enough potential sources of revenues".

Tracz believes his venture is the forerunner of a market where the primary literature is free, and where commercial publishers provide other services, such as reviewing, reporting and alerting. One of BMC's major activities will be selling database services in partnership with other companies and groups of scientists, he adds.

"Easy access stimulates usage, and barriers reduce usage," says Andrew Odlyzko of AT\&T Research Laboratories in Florham Park, New Jersey, who studies electronic publishing. He says that scientists will soon find that unless their papers are freely available, they might as well not be written. 